\title{
Examining the Impact of Syrian Refugee Crisis on the Lebanese Economy: The Case of Banking Sector
}

\author{
Dr. Mohammad Knio ${ }^{1}$, Ms. Mona Ayoub ${ }^{2}$ \\ ${ }^{1}$ International University of Beirut, School of Business, Salumi Road, Lebanon \\ ${ }^{2}$ Arts, Sciences and Technology University in Lebanon Department of Management, Cola, Lebanon
}

\begin{abstract}
:
Objective: The purpose of this paper is to shed the light on how the Syrian refugee crisis affected the Lebanese economy, through illustrating the case of the banking sector in the Bekaa Valley between 2011 and 2016. Among its stated objectives, this research seeks to be as a reference for scholars showing interest in this subject. The focus of the study was directed toward the impact on the banking sector by highlighting on the following indicators: loan and deposit growth, interest rates, and on the impact of cash for work programs for refugees and as well as on the Lebanese economy.

Methodology: The Mono-method was used in this research study which focused on one single qualitative technique, utilizing the in depth interview data collection method. Choosing this technique helped in answering the research question since we targeted the refugees-which are the cause group- impacting the Lebanese economy, banking sector group specifically high and intermediate level of employees, which are the Humanitarian activists, the intermediaries between refugees and the host community are including economic sector.

Results: The Syrian refugee crisis had no significant impact on the Lebanese banking sector. As a result of the national and international limitations, which are represented by the following factors: Their inability to open checking/saving accounts, take loans or even make investments. However, there was a decrease in interest rate on deposits, where no significant growth in interest rates on loans, increase demand on loans by locals, no significant change in interest rates on local and foreign currencies. On the other hand, Syrian refugee crises had several impacts on other economic sectors such as trade, employment and transportation sectors.

Implication: This research provides an in depth analysis about the impact of Syrian refugee crisis on the Lebanese economy; especially in the banking sector. Results showed that the Syrian refugee crisis had a positive impact on the local trade sector, increase in native unemployment rates (Segal, et al. 2010). Moreover, the cash for work program provided great benefit for registered refugees. With respect to the growth of interest rates, experts from banking sector agreed that there was an increase in demand on loans without any growth in loans interest rates. On the other hand, there was a decrease in interest rates on deposit.
\end{abstract}

Key Words: Impact of Syrian Refugee Crisis, Banking Sector, Lebanese Economy, Cash For Work Programs, UNHCR, NGOs.

\section{Introduction}

Since the Syrian conflict began, it generated over 4.7 Million registered Syrian refugees in our region; including North Africa, Egypt, Iraq, Jordan, Lebanon and Turkey (Girard, 2016). According to the UNHCR, until September 2016, the number of registered Syrian refugees in Lebanon hit 1.17 Million in Lebanon (Ayoub, 2017). This migration has seriously impacted ${ }^{1}$ the Lebanese economy. Yet, the rapid increase in the number of refugees entering Lebanon have created what it's called now Syrian refugee crisis which have impacted several sectors in the Lebanese economy.

\footnotetext{
${ }^{1}$ Based on each observed sectors, this impact may have been positive or negative.
}

With respect to the banking sector, there were few studies, which indirectly discussed the impact of Syrian refugee crisis on this sector, that have been published. Ayoub (2017) points out that from the existing studies, neither clearly identify whether the Syrian refugee crisis has negative, positive or no impact on the banking sector in Lebanon. So, starting from this point, there is a need to have in depth study which identify this impact. In addition, it is very essential to understand how the increase number of refugees have impacted the banking sector, because it is one of the most dynamic sectors in the Lebanese economy. Moreover, many people with interest in banking sector such as economists, financial analysts and most importantly students with finance and banking sector would background absolutely benefit from this type of study. 
The major purpose of conducting this research is to study the impact of Syrian refugee crisis on the Lebanese economy, specifically the banking sector (Ayoub, 2017). The importance of this research lies in shedding the light on how refugee crisis is affecting the banking sector in Lebanon, whether the -effect is negative or positive. This thesis will also try to answer the research question from experts' point of view as well as personal point of view. It can also be used as a reference in the future to other students and/or people with interest in this subject who are seeking to find existing studies about this topic.

Research question: What is the Impact of the Syrian Refugee Crisis on the Lebanese Economy, as observed through the banking sector?

\section{Literature Review}

\section{Refugee crisis: A general overview}

The Flash Back records of refugee movements was proposed by Gil Loescher. He covered almost large number of areas that experienced refugee crisis and gave example about the largest and most dramatic refugee movement that ever happened goes back to the Cold War era which involved nearly 2 to 3 million Iraqi Kurds who streamed toward the borders of Iran and Turkey (Loescher, 1996). 2.5 million Expelled from their homes as a result of ethnic cleansing and millions of Somalis were displaced as a result of brutal intercalant warfare and food shortages. The Palestinian refugee movements toward Jordan since 1948 make up at least half of the Jordan's population (Hudson, 1997). Loescher (1996) has shed the light on the refugee crisis taking place in Afghanistan, Southern Africa and
Central America that began during the last decade and remain largely unresolved as ethnic hatred have hilled the ideological void left after the ending of East-West rivalry in these regions. Population growth, poverty, instability and ethnic conflicts all signal continuing mass movement of populations.

According to o recent report from the 'UNHCR' in 2015, the number of refugees rose to 14.4 million in 2014 (Ayoub, 2017). On June 2016, the 'UNHCR' recorded 21.3 million refugees around the world, over half of whom under the age of 18. These numbers are considered the highest ever and have severely impacted the economies of the countries welcoming refugees (Ayoub, 2017). Refer to graph 1.

\section{Economic Integrations of Refugees in Developed and Developing Countries}

A model for the economic dimension of refugee integration by Tom Kuhlman. He proposed a list of criteria for assessing economic integration (Kuhlman, 1990). They include: 1) The adequate participation in the economy. 2) An income which allows an acceptable standard of living. 3) The Access equal to that of the host population to those goods and services to which access is not determined solely by income levels. 4) The impact of refugees on the host society having been such that, on balance, the position of the various socio-economic categories within the indigenous population.

Graph 1: Movement of Refugees between 1994 and 2016 based on UNHCR data (source: Ayoub, 2017)

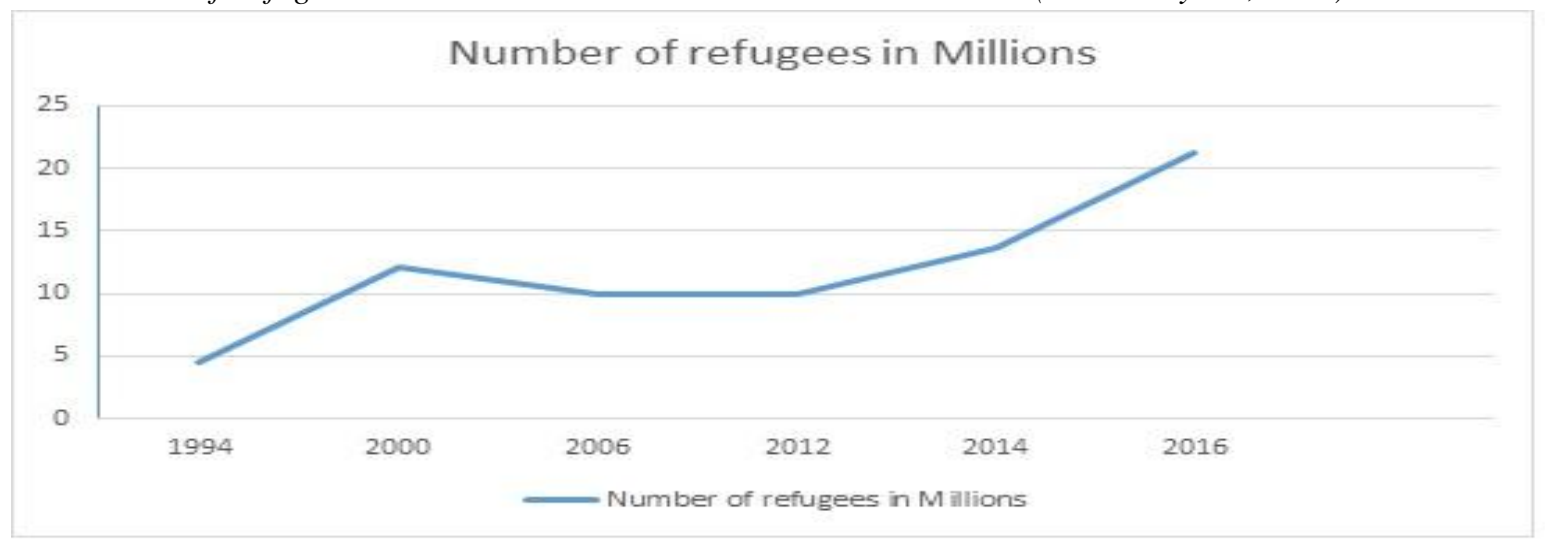

The fourth criterion indicated the economic impact of the refugees which he said that measuring this impact is actually very difficult: out of total economic change which the host region will have undergone since the influx of refugee began. Kuhlman (1990) designed a model for the economic dimension of integration, incorporating the determinants shown in Figure 1. According to him, this model can serve as a framework for assessing and analyzing the economic integration of refugees. This model acknowledges that it is not impossible to apply by highlighting the success of Kassala (Kuhlman, 1990). And, that It is always possible to select a small part of the integration process for a partial analysis as long as the overall picture is kept in mind.

Economic Integration in Canada, Sweden, and Uganda According to Ayoub (2017), and in the table below, studying the economic integration of refugees in developed 
and developing countries, Canada, Sweden, and Uganda, between 1980s and 2000s, results showed the integration varied between positive, negative or even no impact based on several factors in each of these countries (c.f. Head \&
Ries 1998; Rooth, 1999; George, 2002; Devoretz, Pivnenko, \& Beiser, 2004; Dryden-Peterson \& Hovil, 2009). The table below summarized the results.

Figure 1: A Model for the economic dimension of refugee integration (Kuhlman, 1990)

\begin{tabular}{|c|c|c|c|}
\hline \multicolumn{4}{|c|}{ Determinants } \\
\hline $\begin{array}{c}\text { Characteristics of } \\
\text { Refugees }\end{array}$ & $\begin{array}{c}\text { Flight-related } \\
\text { factors }\end{array}$ & $\begin{array}{c}\text { Host-related } \\
\text { factors }\end{array}$ & Policies \\
\hline \multicolumn{2}{|c|}{} \\
\hline $\begin{array}{c}\text { Residence in Host } \\
\text { country }\end{array}$ & Outcomes \\
\hline Non-economic & Economic integration \\
\hline \hline
\end{tabular}

Table 2. Economic Impact and Integration of refugees in developed and developing countries (Source: Ayoub, 2017)

\begin{tabular}{|c|c|c|c|c|}
\hline Anthor: & Location & \multicolumn{2}{|l|}{ Impact $(+1-)$} & Studies peried \\
\hline Devoretz, Pifrenenlio \& Beiser & Canada & \multicolumn{2}{|l|}{+} & $1980-2001$ \\
\hline Dan-Olof Rooth & Sweden & \multicolumn{2}{|l|}{-} & $1987-1991$ \\
\hline Segal, Diliott, \& Mayadas & Sweden & \multicolumn{2}{|l|}{$-1+$} & $1960-2005$ \\
\hline \multirow[t]{2}{*}{ Dryden-Peterson \& Hovil, } & \multirow[t]{2}{*}{ Uganda } & Self-settled & + & \multirow[t]{2}{*}{$1990 \mathrm{~s}-2003$} \\
\hline & & In camps & non & \\
\hline
\end{tabular}

\section{Lebanon and Refugee Crisis: A general background}

This part mainly focuses on Three important stages for the history of refugees in Lebanon:

1- Refugees and Lebanese Economy between 1948 and 1974: This stage demonstrate the flee of Palestinians seeking refugee in Lebanon after the Israeli invasion to Palestine and how the refugees employed their money and labor into the Lebanese economy until the civil war began in Lebanon (e.g. Nasr, 1978; Hudson, 1997).

2- Growth of Banking: This stage focuses on the growth of the banking sector in Lebanon. The number of Lebanese banks increased from 10 in the mid of 1950 s to 55 in 1965 . The most important Lebanese bank at that time, Intra, controlled big corporations in the country. The table below shows the fluctuation in the number of banks in Lebanon (Ayoub, 2017).

At the end of 1966 many internal and external factors, including financing Palestinian Militias, led to the collapse of Intra and other Lebanese banks (Hudson, 1997).
Table 3: Fluctuation of number of banks in Lebanon (19551974)

\begin{tabular}{llllc}
\hline Years & 1955 & 1965 & 1966 & 1974 \\
\hline Number of Banks & 10 & 55 & 55 & 25 \\
\hline & & & & Created by: Mona Ayoub
\end{tabular}

3- Common Stories debates: This stage discussed different points of views with regards to Palestinian refugees in the Lebanese economy (c.f. Hudson, 1997). They all agreed that there's no hope that these refugees will go back to their own country on the long term. They became a part of the Lebanese community and engaging in economic and financial activities in Lebanon (Ayoub, 2017).

\section{Syrian refugees' integration and impact on the Lebanese} Economy

This section focuses on how the number of Syrian refugees increased dramatically since the clashes started in Syria in March of 2011. Also it argues different points of views whether the Syrian refugees has integrated in Lebanese 
economy or not and what impact they had based each sector. The table on the next page shows the impact of Syrian refugee crisis on different sectors of the Lebanese economy according to different views (Calì, et al., 2015).

So, in the case of Lebanon, which is categorized in developing countries, the impact of refugees varies throughout time. For Palestinian refugees, opinions were and still vary between researchers and economists (Hudson, 1997). Some agree that they have positive impact and other say they have negative impact on the Lebanese economy (c.f. Calì, et al., 2015).
With respect to Syrian refugees, the crisis is still ongoing and through this literature review results showed that Syrian refugees had both negative and positive impact on the Lebanese economy in different sectors. What was interesting was that there was a common opinion that agreed that Syrian refugee crisis had negative impact on the trade and tourism sectors in Lebanon. The Real Estate sector had a positive impact. On the other hand, there were various opinions about the Banking/Finance sector whether refugees had positive or negative impact (Dryden-Peterson \& Hovil, 2009; Calì, et al., 2015).

Table 4: Impact of Syrian refugee crisis on different sectors of the Lebanese economy according to different views. (c.f. Chaaban, et al. 2010; Holmes, 2013; Mouamar, 2013; Mudallali, 2013; Cali et al., 2015; Ayoub, 2017)

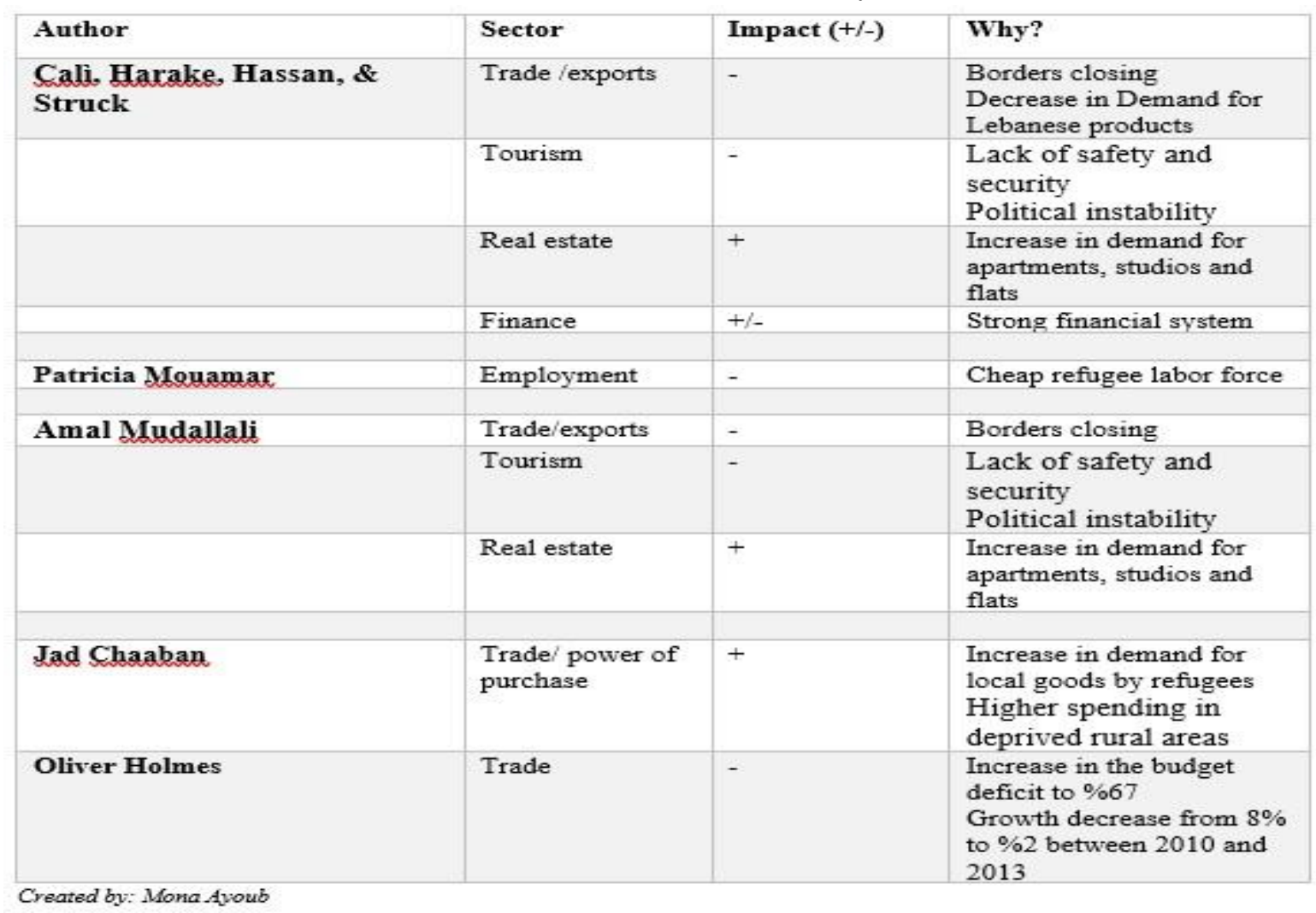

\section{Research Methodology}

This study is going to follow the Interpretivism philosophy. It will interpret the roles of Syrian refugees in having an impact on the Banking sector. Also it will highlight the point of view of banks, refugees as well as NGOs stances (Saunders et al., 2009).

Following Saunders et al. (2009), in this research we are going to use the inductive approach, since we are trying to find out what's going on with the banking sector in Lebanon. How it is affected by the Syrian refugee crisis? Was it a positive or negative impact? What are the possible actions that should be taken to adapt this phenomenon? For this purpose, it is important to focus on using qualitative data collection in which will be based on interviewing people in direct relation with the topic as well as using selfobservations. Therefore, the Mono-method will be an appropriate choice in this research study which will focus on a single qualitative technique, in depth interviews. Single case study is often used where it represents a critical case or extreme unique case (Saunders et al., 2009).

The participants in this research were characterized of specialists in the banking sector, NGO employees as well as refugees themselves, using methods listed in Saunders et al., (2009). The size of this small sample is estimated to be between six to twelve people. Interviews will be conducted with three persons from different positions in the banking sector, 3 persons from NGO sector and 3 refugees (c.f. Saunders et al., 2009). The Bekaa valley will be the geographic focus of this study, since the largest number of refugees is based in this area. 


\section{Results}

In Figures 2, 3 and 4, we have demonstrated the findings of interviewing our groups and their three different point of views which emphasize the impact of Syrian refugee crisis on the Lebanese economy in general and the banking sector in specific term. These three opinions are the following: NGOs opinion, Refugee opinion and Banking sector opinion. (Dryden-Peterson \& Hovil, 2009)

All interviewees agreed that the Syrian refugee crisis has both, a negative and a positive impact on the Lebanese economy depending on each economic sector. Table 3, on the next page, shows the evaluation of our findings (Ayoub, 2017).

Figure 2: Refugees' point of view. (Ayoub, 2017)

$\begin{gathered}\text { Refugees' } \\ \text { point of } \\ \text { view }\end{gathered}$
$\begin{aligned} & \text { Ability to open a bank account } \\ & \text { Syrians/Refugees are not willing open bank accounts in Lebanese banks } \\ & \text { It has great benefit for registered refugees who are benefiting from the full program. Also } \\ & \text { for local vendors }\end{aligned}$
$\begin{aligned} & \text { Impact on Lebanese economy and Banking sector } \\ & \text { On Lebanese economy: Both positive and negative impact } \\ & \text { On banking sector: No impact, however it might has negative impact due to massive } \\ & \text { amount of refugees attempting to withdraw from ATMs }\end{aligned}$

Figure 3: NGOS' point of view. (Ayoub, 2017)

$\begin{aligned} & \text { Experience with the banking sector } \\ & \text { Difficult experience for both NGOs established before and after the refugee crisis due to } \\ & \text { several restrictions } \\ & \text { point of } \\ & \text { view }\end{aligned}$
$\begin{aligned} & \text { Cash Assistant Program } \\ & \text { A lot of benefits for refugees. It provide freedom of choice, self-esteem and self-control } \\ & \text { for refugees in identifying their needs }\end{aligned}$
$\begin{aligned} & \text { Impact on Lebanese economy and Banking sector } \\ & \text { On Lebanese economy: Both positive and negative impact } \\ & \text { On banking sector: } 3 \text { different views: positive, negative or no impact }\end{aligned}$

Figure 4: Banking sectors' point of view. (Ayoub, 2017)

Contribution of Syrians/Syrian refugees in the banking sector
Decreased dealing with Syrians/Syrian refugees after the crisis. Put limitations for
existing Syrian customers. Limited contribution and almost invisible
$\begin{aligned} & \text { Banking } \\ & \text { pector } \\ & \text { view }\end{aligned}$
$\begin{aligned} & \text { Growth in Interest rates (deposits, loans and currencies) } \\ & \text { however increase in demand on loans by locals. No significant change in interest on local } \\ & \text { and foreign currencies }\end{aligned}$
$\begin{aligned} & \text { Impact of Cash assistant programs to Syrian refugees on banking sector } \\ & \text { For Syrian refugees, great benefit } \\ & \text { For banking sector, negative impact; required extra unpaid work for employees due to the } \\ & \text { massive amount of ATM refugee users }\end{aligned}$
$\begin{aligned} & \text { Impact of Syrian refugee crisis on the banking sector } \\ & \text { No significant impact on the banking sector simply because banks don't open bank accounts. } \\ & \text { However, banks lost opportunities to open bank accounts for wealthy Syrians, closed braches in } \\ & \text { Syria. Also the ATM issue had negative impact }\end{aligned}$


Table 3: Evaluation of findings (Ayoub, 2017).

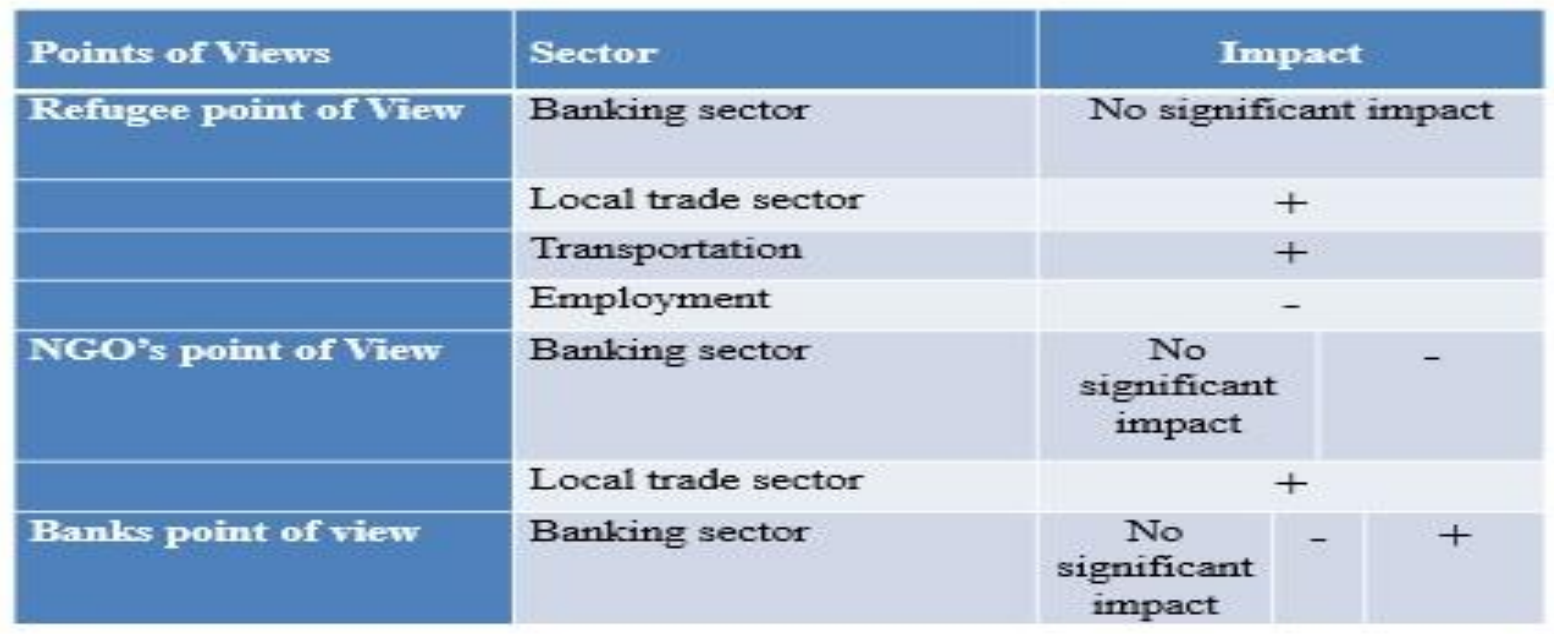

\section{Conclusion}

This research provides us with evidence based on different direct groups that the banking sector in Lebanon is similar to many banking sectors in many developing countries. Many decisions taken by the Central Bank are associated with external factors and pressures by other big countries. In addition to the recommended actions that should be taken to adapt with the on-going Syrian refugee crisis, banking sector as well as many other sectors should have more freedom in taking decisions and more efforts should be implemented to identify problems and risks more accurately.

Why banking sector should be completely influenced and obliged in a way or another to apply foreign policies? Why most of the countries' decisions, actions or even policies should be highly influenced by other countries? Until we set ourselves free and be able to change the decision makers and political layer in this country, maybe the banking sector and other sectors in Lebanon will have their own stances. Perhaps we should go back to the main reason of the Syrian revolution and how the citizens end up as refugees.

\section{Recommendations}

Our recommendations in this paper can be summarized by the following points: (1) Reconsidering lost investment opportunities. (2) Identifying more accurately the suspicious lists in collaboration with the Lebanese security forces in order to benefit from missing opportunities. (3) More flexibility with International and local NGOs which are bringing lots of money to the country.

\section{References}

1. Ayoub, M., 2017. Impact of Syrian Refugee Crisis On The Lebanese Economy: The Case of Banking Sector. MBA thesis presented at the AUL University.

2. Calì, M., Harake, W., Hassan, F., \& Struck, C. (April 2015). "The Impact of the Syrian Conflict on Lebanese Trade". Report published by the World
Bank. Retrieved on Nov 30, 2016, from http://documents.worldbank.org/curated/en/908431 468174247241/pdf/96087-WP-P148051-PUBLICBox391435B-Syria-Trade-Report.pdf

3. Chaaban, J., Ghattas, H., Habib, R., Hanafi, S., Sahyoun, N., Salti, N., Seyfert, K., Naamani, N. (2010), "Socio-Economic Survey of Palestinian Refugees in Lebanon", Report published by the American University of Beirut (AUB) and the United Nations Relief and Works Agency for Palestine Refugees in the Near East (UNRWA).

4. DeVoretz, Don J. and Pivnenko, Sergiy and Beiser, Morton, The Economic Experiences of Refugees in Canada (March 2004). IZA Discussion Paper No. 1088. Available at

SSRN: https://ssrn.com/abstract=526022

5. Dryden-Peterson, S., \& Hovil, L. (2009). A remaining hope for durable solutions: Local integration of refugees and their hosts in the case of Uganda. Refuge: Canada's Journal on Refugees, 22(1), 31-32.

6. Hudson, M. C. (1997). Palestinians and Lebanon: The common story. Journal of Refugee Studies, 10(3), 243-260.

7. George, U. (2002). A needs-based model for settlement service delivery for newcomers to Canada. International Social Work, 45(4), 465480.

8. Girard, M., 2016. Syrian refugees in Lebanon: A turning point? The Long-Term Challenges of Forced Migration: Perspectives from Lebanon, Jordan and Iraq, LSE Middle East Centre Collected Papers, Volume 6, (September 20 2016).

9. Head, K., \& Ries, J. (1998). Immigration and trade creation: Econometric evidence from Canada. The Canadian Journal of Economics, 31(1), 47-62.

10. Kuhlman, T. (1990). Burden or boon? A study of Eritrean refugees in the Sudan. VU University Press. 
"Examining the Impact of Syrian Refugee Crisis on the Lebanese Economy: The Case of Banking Sector"

11. Loescher, G. (1996). Beyond charity: International Cooperation and the Global Refugee Crisis. Oxford University Press.

12. Mouamar, P. (August 24 2013). Viewpoints: Impact of Syrian refugees on host countries. BBC World. Retrieved from http://www.bbc.com/news/world-23813975

13. Mudallali, A. (February 2013). The Syrian Refugee Crisis is Pushing Lebanon to the Brink. Retrieved November 30, 2016, from Woodrow Wilson Center, https://www.wilsoncenter.org/sites/default/files/syr ian refugee crisis pushing lebanon to brink.pdf

14. Nasr, S. (1978). Backdrop to civil war: The crisis of Lebanese capitalism. MERIP Reports 3-13.

15. Holmes, O. (April 17 2013). Syrian refugees burden and benefit for Lebanese economy. Retrieved November 30, 2016, from http://www.reuters.com/article/us-crisis-lebanonrefugees-idUSBRE93G0MW20130417

16. Rooth, D.-O. (1999). Refugee immigrants in Sweden - educational investments and labour market integration. $\mathrm{PhD}$ Thesis defended at the University of Lund, Sweden.

17. Saunders, M., Lewis, P., \& Thornhill, A. (2009). Research Methods For Business Students (Fifth edition), Pearsons.

18. Segal, U. A., Elliott, D., \& Mayadas, N. S. (2010). Immigration Worldwide: Policies, Practices, and Trends. Oxford University Press. 